\title{
Free radical scavenging behavior of ten exotic tropical fruits extracts
}

\author{
Maria S.M. Rufino ${ }^{\text {a }}$, Ricardo E. Alves ${ }^{\text {a }}$, Fabiano A.N. Fernandes ${ }^{\text {b,* }}$, Edy S. Brito ${ }^{\text {a }}$ \\ a Embrapa Agroindústria Tropical, R. Dra. Sara Mesquita, 2270, Pici, 60511-110 Fortaleza, CE, Brazil \\ b Universidade Federal do Ceará, Departamento de Engenharia Química, Campus do Pici, Bloco 709, 60455-760 Fortaleza, CE, Brazil
}

\section{A R T I C L E I N F O}

\section{Article history:}

Received 29 March 2010

Accepted 5 July 2010

\section{Keywords:}

Tropical fruit

Radical scavenger

DPPH

Kinetics

\begin{abstract}
A B S T R A C T
The antiradical capacity (radical scavenger capacity, RSC) of bacuri, cajá, camu-camu, carnauba, gurguri, jabuticaba, jambolão, juçara, murta, black puçá and puçá were studied using the 2,2-diphenyl-1picrylhydrazyl radical $(\mathrm{DPPH} \bullet)$ assay. To determine their RSC, the second-order rate constants $\left(k_{2}\right)$ for the oxidation of these extracts by DPPH • were calculated. The values of $k_{2}$ were compared to natural and synthetic antioxidants. The $k_{2}$ values (L/mol g s), in methanol at $25^{\circ} \mathrm{C}$, were $69.52,26.03,22.20,18.04,17.23$, $16.56,15.60,10.03,7.72$ and 4.15 for camu-camu, murta, gurguri, carnauba, jabuticaba, black puçá, jambolão, cajá, juçara and bacuri.
\end{abstract}

(c) 2010 Elsevier Ltd. All rights reserved.

\section{Introduction}

High consumption of fruits is associated with a lowered incidence of degenerative diseases, including cancer, heart disease, inflammation, arthritis, immune system decline, brain dysfunction and cataracts (Di Matteo \& Esposito, 2003; Gerber et al., 2002; KrisEtherton et al., 2002). Fruits contain high levels of biologically active components that impart health benefits beyond basic nutritional value. Within the biologically active components, natural antioxidants have attracted interest because of their safety and potential therapeutic effect. These antioxidants are capable of acting as free radical scavengers, peroxide decomposers, singlet oxygen quenchers, enzyme inhibitors and synergists.

Generation of active oxygen and free radicals is important both in food systems and in biological systems (Espin, Soler-Rivas, Wichers, \& García-Viguera, 2000; Rattan, 2006; Suja, Jayalekshmy, \& Arumughan, 2004). Oxidation is an essential biological process for energy production in many living organisms. However, excessive reactive oxygen species, produced in vivo during some oxidative reactions, are not only strongly associated with lipid peroxidation but also involved in the development of some diseases such as cancer, inflammation, atherosclerosis, and aging (Moskovitz, Yim, \& Chock, 2002). In foods, the process of autoxidation and development of rancidity is caused by free radicals (Shahidi, Janitha, \& Wanasundara, 1992).

In the past years, attention has been given to ascorbic acid, $\alpha$ tocopherol, tocotrienols, $\beta$-carotene, and in natural antioxidants of plant origin because they have greater application in the food industry for increasing the stability and shelf life of food products (Rice-Evans

\footnotetext{
* Corresponding author. Tel.: + 5585336 9611; fax: + 558533669610 .

E-mail addresses: fabiano@ufc.br (F.A.N. Fernandes), edy@cnpat.embrapa.br (E.S. Brito).
}

\& Miller, 1995). Moreover, they also find use as nutraceuticals and phytoceuticals as they have significant impact on the status of human health and disease prevention (Noguchi \& Nikki, 2000).

The antioxidant activity can be expressed in terms of radical scavenging ability during reaction with a specific radical such as $\left[\mathrm{DPPH} \bullet\right.$ or [ $\mathrm{LOO}^{\bullet}$. The model of scavenging stable $\mathrm{DPPH} \bullet$ is a widely used method to evaluate the RSC in a relatively short time compared to other methods (Brand-Williams, Cuvelier, \& Berset, 1995; SánchezMoreno, Larrauri, \& Saura-Calixto, 1998). Free radical scavenging is the generally accepted mechanism for antioxidants inhibiting lipid oxidation.

The scavenging of DPPH• by radical scavengers can be summarized as:

$\mathrm{DPPH}^{\bullet}+\mathrm{FE} \rightarrow \mathrm{DPPH}-\mathrm{H}+\mathrm{A} \bullet$

$\mathrm{DPPH} \bullet+\mathrm{A} \bullet \rightarrow \mathrm{DPPH}-\mathrm{A}$

$\mathrm{A} \bullet+\mathrm{A} \bullet \rightarrow \mathrm{A}-\mathrm{A}$

Where FE is a scavenger of the fruit extract, $A \bullet$ is radical.

The newly formed radical $\left(A^{\bullet}\right)$ can mainly follow radical-radical interaction to render stable molecules via radical disproportionation (collision of radicals with abstraction of an atom by one radical to another - Eqs. (2) and (3)) although these secondary reactions are greatly hindered (Aruoma, 1998; Chimi, Cillard, Cillard, \& Rahmani, 1991). It is important to notice that when studying fruit extracts there is the existence of several possible radical scavenger species in the extracts. 
The aim of this study was to kinetically characterize the free radical scavenger capacity of bacuri (Platonia insignis), cajá (Spondias mombin), camu-camu (Myrciaria dubia), carnauba (Copernicia prunifera), gurguri (Mouriri guianensis), jabuticaba (Myrciaria cauliflora), jambolão (Syzygium cumini), juçara (Euterpe edulis), murta (Blepharocalyx salicifolius), puçá (Mouriri elliptica) and black puçá (Mouriri pusa) by using 2,2-diphenyl-1-picrylhydrazyl radical $(\mathrm{DPPH} \bullet)$ to evaluate their potential as source of antioxidant.

These exotic fruits were studied because they are widely consumed in certain areas in Brazil. Bacuri, camu-camu, carnauba, gurguri, murta, black puçá and puçá are widely consumed in the Amazon region. Jabuticaba and jambolão are widely consumed in the Southeast of Brazil and cajá and juçara are widely consumed in the Northeast of Brazil. These fruits have a yellow to black color indicating a possible source of anthocyanins. More information on these fruit can be obtained in Rufino et al. (2009).

\section{Materials and methods}

\subsection{Samples}

Bacuri was collected at the producer at the city of Coelho Neto, MA, Brazil. Camu-camu was obtained from the producer in the city of Belém, PA, Brazil. Carnauba was collected at the producer in the city of Maracanaú, CE, Brazil. Gurguri, cajá, black puçá and puçá was obtained from the producer in the city of Beberibe, CE, Brazil. Jabuticaba was obtained from the producer in the city of Ibiapaba, CE, Brazil. Jambolão was obtained from the producer in the city of Trairi, CE, Brazil. Juçara was obtained from the producer in the city of São Paulo, SP, Brazil. Murta was obtained from the producer in the city of Crato, CE, Brazil.

The reagent 2,2-Diphenyl-1-picrylhydrazyl (DPPH•) was supplied by Sigma (St. Louis, USA). All other reagents (acetone and methanol) were of analytical grade and were also supplied by Vetec (Duque de Caxias, RJ, Brazil).

\subsection{Extracts preparation and chemical analysis}

The extracts were obtained in the year of harvest, and stored at $4{ }^{\circ} \mathrm{C}$ until analyzed. The extracts were prepared starting from $5 \mathrm{~g}$ of the fresh fruit. The fruits were crushed, weighed, and extracted initially with $40 \mathrm{~mL}$ methanol:water $(50: 50, \mathrm{v} / \mathrm{v})$ at room temperature for $60 \mathrm{~min}$. The extract was centrifuged at 25,400 $\mathrm{g}$ for $15 \mathrm{~min}$. The supernatant was recovered and $40 \mathrm{~mL}$ acetone:water (70:30, v/v) was added to the residue at room temperature for $60 \mathrm{~min}$. The extract was centrifuged again at $25,400 \mathrm{~g}$ for $15 \mathrm{~min}$. The supernatants from these extractions were combined and made up to $100 \mathrm{~mL}$ with distilled water (Saura-Calixto, Goñi, Mañas, \& Abia, 1991) and assayed spectrophotometrically at $700 \mathrm{~nm}$ by the Folin-Ciocalteau method to determine the total phenolics in the fruit, using gallic acid as standard (Obanda \& Owuor, 1997). The results were expressed as mg of gallic acid/100 $\mathrm{g}$ of fruit. The fruits were also analyzed for vitamin C (Strohecker \& Henning, 1967). Full chemical analysis of the fruit extracts including ABTS, FRAP, total phenolic content and $\beta$-carotene bleaching can be found in Rufino et al. (2010).

\subsection{Free radical scavenging by $\mathrm{DPPH} \bullet$}

DPPH was dissolved in methanol. Experiments were performed on freshly prepared solutions of radical, which in the absence of radical scavengers were stable for more than 1 day. The presence of methanol was required to enhance the solubility of the extract to reach pseudo-first order assay conditions where the initial fruit extract concentration was much lower than the initial radical concentration $\left([\mathrm{DPPH} \bullet]_{0}>[\mathrm{FE}]_{0}\right)$. Specific antiradical activity assay conditions were as follows: DPPH $60 \mu \mathrm{mol} / \mathrm{L}$; bacuri $300-$ 400 g/L, cajá 100-300 g/L, camu camu 0.5-20 g/L, carnauba 25-
200 g/L, gurguri 5-50 g/L, jabuticaba $2.5-50$ g/L, jambolão $10-50$ g/L, juçara 5-50 g/L, murta 10-50 g/L, black puçá 5-100 g/L and puçá $5-100 \mathrm{~g} / \mathrm{L}$.

The free radical-scavenging activity of fruits was measured using the method described by Brand-Williams et al. (1995), with modifications. A $0.06 \mathrm{mM}$ solution of DPPH in methanol was prepared and an aliquot of $100 \mu \mathrm{l}$ of the antioxidant/fruit extract solution was added to $3.9 \mathrm{~mL}$ of the DPPH solution. The decrease in absorbance at $515 \mathrm{~nm}$ was measured at $0,1,2,3,4,5,6,7,8,9$ and $10 \mathrm{~min}$, and then every $5 \mathrm{~min}$ until the reaction reached a plateau. The spectrophotometric assays were recorded using a UV-Vis Genesisspectrophotometer (Spectronic Instruments, Rochester, NY). Temperature was controlled at $25{ }^{\circ} \mathrm{C}$ with a circulating water bath. As a reference the solvent mixture instead of the extract was used. The results were obtained in triplicate and expressed as mean \pm SD.

\subsection{Kinetic analysis}

Fitting of the experimental data were carried out by using the Levenberg-Marquardt method (Marquardt, 1963) that was built using FORTRAN 90. Recording of spectrophotometric data was taken until the disappearance of $\mathrm{DPPH} \bullet$ in the presence of fruit extracts occurred.

Second-order rate constants $\left(k_{2}\right)$ were calculated to determine the RSC of the tropical fruits. The antioxidant of the fruit extract was depleted from the medium under pseudo-first order conditions, $\left([\mathrm{DPPH} \bullet]_{0}>>[\mathrm{FE}]_{0}\right)$ following the equation:

$$
\begin{aligned}
& \frac{d[\mathrm{FE}]}{d t}=-k[\mathrm{FE}] \\
& {[\mathrm{FE}]=[\mathrm{FE}]_{0} \times \exp (-k t)}
\end{aligned}
$$

where $[\mathrm{FE}]$ is the fruit extract concentration, $[\mathrm{FE}]_{0}$ is the initial fruit extract concentration, $k$ is the pseudo-first order kinetic rate constant, and $t$ is the time.

The concentration of $\mathrm{DPPH} \bullet$ was calculated by mass balance using the following equation:

$[\mathrm{DPPH} \bullet]=[\mathrm{DPPH} \bullet]_{0}-[\mathrm{FE}]_{0} \times \exp (-k t)$

where $[\mathrm{DPPH} \bullet]$ is the radical concentration, $[\mathrm{DPPH} \bullet]_{0}$ is the initial radical concentration, $k$ is the pseudo-first order kinetic rate constant, and $t$ is the time.

$\mathrm{DPPH} \cdot$ concentration in the reaction medium was calculated according to the method of Brand-Williams et al. (1995) obtained from the calibration curve with the equation as determined by linear regression:

$\operatorname{Abs}(515 \mathrm{~nm})=0.0137 \cdot[\mathrm{DPPH} \cdot]-0.029$

where [DPPH•] is expressed as $\mu \mathrm{mol} / \mathrm{L}$.

The pseudo-first order kinetic rate constant $(k)$ was linearly dependent on the concentration of the fruit extract and the secondorder rate constant $\left(k_{2}\right)$ was determined by the equation (Mukai, Morimoto, Kikuchi, \& Nagaoka, 1993; Shi \& Niki, 1998):

$\frac{d[\mathrm{DPPH} \bullet}{d t}=-k_{2} \times[\mathrm{FE}] \times[\mathrm{DPPH} \bullet]$

This method to calculate the second-order kinetic rate constant $\left(k_{2}\right)$ differs from the method presented by Brand-Williams et al. (1995), which is based on the assumption that the DPPH• concentration is much lower than the antioxidant concentration $\left([\mathrm{DPPH} \bullet]_{0}<<\right.$ $\left.[\mathrm{AH}]_{0}\right)$. 


\section{Results}

The results showed that the absorbance decreased as a result of a color change from purple to yellow, as the radical was scavenged by antiradicals, through donation of hydrogen, to give the reduced form DPPH-H (Eq. 3). The oxidation reaction is truly a second order reaction since two species react to form one or more oxidation products. The reaction may be assumed as a pseudo-first order reaction if one of the reactants is in excess, as assumed by Brand-Williams et al. (1995). Some authors do not make this simplification (Mukai et al., 1993; Shi \& Niki, 1998), as in this work. Since a simplification is not made, the obtained kinetic parameters are more accurate.

In the presence of the tropical fruit extracts, a decrease in the absorbance at $515 \mathrm{~nm}$ was measured until the fruit antioxidant was depleted under pseudo-first order assay conditions. The pseudo-first order rate constant, $k$, was linearly dependent on initial radical scavenger concentration ([FE $\left.]_{0}\right)$.

The second-order rate constants, $k_{2}$, which represents the rate at which DPPH can be oxidized by $1 \mathrm{~g}$ of fruit, were calculated from Eq. (8) and are presented in Table 1. This rate constant is related to the RSC present in the fruit extracts and higher $k_{2}$ values corresponds to a better RSC. All ten fruits presented more than one kinetic period and camu-camu have presented three kinetic periods. Fruits may present several natural antioxidants in their composition with different scavenging capacity and in this case the scavenging of DPPH• will be carried out by all antioxidants present in the fruit. Antioxidants with higher RSC will scavenge the DPPH $\bullet$ radicals at a higher rate while antioxidants with lower RSC will take more time to reduce the amount of $\mathrm{DPPH} \cdot$ present in the assay.

The RSC obtained for the tropical fruits studied herein was compared to that of other synthetic (BHT) and natural ( $\alpha$-tocopherol) antioxidants. $\alpha$-Tocopherol (vitamin E) is a natural antioxidant abundant in oils and other foodstuffs with high fat content, such as butter, margarine, etc. (Shahidi et al., 1992). Vitamin E was the most powerful antioxidant assayed with a $k_{2}$ value of $37.35 \mathrm{~L} / \mathrm{mol} \mathrm{gs}$. This results was similar to the result obtained using the data published by Suja et al. (2004), which obtained a $k_{2}$ value of $37.10 \mathrm{~L} / \mathrm{mol} \mathrm{gs}$ for $\alpha$ tocopherol.

The order of RSC, according to $k_{2}$ values (the higher $k_{2}$ value, the better the RSC) was camu-camu $>\alpha$-tocopherol $>$ murta $>$ gurguri $>$ carnauba $>$ jabuticaba $>$ black puçá $>$ cajá $>$ juçara $>$ puçá $>$ bacuri $>$ BHT (Table 2). The tropical fruits studied herein presented $k_{2}$ values ranging from 4.15 to $69.52 \mathrm{~L} / \mathrm{mol} \mathrm{gs}$ (Table 2). The results show that camu-camu is a very powerful antioxidant, presenting an antioxidant capacity $119 \%$ higher than $\alpha$-tocopherol. The results also showed that all fruits studied herein presented a higher activity compared to BHT.

The activity of the Brazilian tropical fruits was also high if compared to other antioxidants reported in the literature. Suja et al. (2004) have studied the RSC of antioxidants compounds of sesame (Sesamum indicum L.) and found that the purified sesamol showed an

Table 1

Bioactive compounds $(\mathrm{mg} / 100 \mathrm{~g}$ fresh matter) in 10 exotic tropical fruits.

\begin{tabular}{lcc}
\hline Fruit extract & Vitamin C & Total anthocyanins \\
\hline Bacuri (Platonia insignis) & $2.4 \pm 0.3$ & $0.3 \pm 0.2$ \\
Cajá (Spondias mombin) & $26.5 \pm 0.5$ & $3.3 \pm 0.2$ \\
Camu-camu (Myrciaria dubia) & $1882 \pm 43.2$ & $42.2 \pm 17.0$ \\
Carnaúba (Copernicia prunifera) & $78.1 \pm 2.6$ & $4.1 \pm 0.1$ \\
Gurguri (Mouriri guianensis) & $27.5 \pm 0.2$ & $3.3 \pm 0.2$ \\
Jabuticaba (Myrciaria cauliflora) & $238 \pm 2.2$ & $58.1 \pm 0.9$ \\
Jambolão (Syzygium cumini) & $112 \pm 5.8$ & $93.3 \pm 3.4$ \\
Jussara (Euterpe edulis) & $186 \pm 43.3$ & $192 \pm 43$ \\
Murta (Blepharocalyx salicifolius) & $181 \pm 1.8$ & $143 \pm 0.5$ \\
Black Puçá (Mouriri pusa) & $28.9 \pm 1.4$ & $103 \pm 21$ \\
Puçá (Mouriri elliptica) & $41.1 \pm 6.7$ & $3.7 \pm 0.8$ \\
\hline
\end{tabular}

Table 2

Second-order kinetic rate constants $\left(k_{2}\right)$ for the reaction between DPPH and antioxidant compounds.

\begin{tabular}{|c|c|c|c|}
\hline & $k_{2}$ (phase 1$)$ & $k_{2}$ (phase 2) & $k_{2}$ (phase 3) \\
\hline & {$[\mathrm{L} / \mathrm{mol} \mathrm{gs}]$} & {$[\mathrm{L} / \mathrm{mol} \mathrm{gs}]$} & [L/mol gs] \\
\hline \multicolumn{4}{|l|}{ Fruit extract } \\
\hline Bacuri (Platonia insignis) & $4.15 \pm 0.43$ & $1.23 \pm 0.06$ & - \\
\hline Cajá (Spondias mombin) & $10.03 \pm 0.51$ & $2.97 \pm 1.37$ & - \\
\hline Camu-camu (Myrciaria dubia) & $69.24 \pm 5.72$ & $2.01 \pm 0.99$ & $0.06 \pm 0.03$ \\
\hline Carnaúba (Copernicia prunifera) & $18.04 \pm 0.86$ & $5.33 \pm 0.75$ & - \\
\hline Gurguri (Mouriri guianensis) & $22.20 \pm 1.11$ & $5.51 \pm 0.28$ & - \\
\hline Jabuticaba (Myrciaria cauliflora) & $17.23 \pm 0.86$ & $3.11 \pm 0.16$ & - \\
\hline Jambolão (Syzygium cumini) & $15.60 \pm 0.78$ & $4.14 \pm 1.28$ & - \\
\hline Juçara (Euterpe edulis) & $7.72 \pm 0.39$ & $0.10 \pm 0.01$ & - \\
\hline Murta (Blepharocalyx salicifolius) & $26.03 \pm 1.30$ & $12.33 \pm 2.53$ & - \\
\hline Black Puçá (Mouriri pusa) & $16.56 \pm 1.68$ & $0.14 \pm 0.01$ & - \\
\hline Puçá (Mouriri elliptica) & $6.72 \pm 0.21$ & $0.31 \pm 0.01$ & - \\
\hline \multicolumn{4}{|l|}{ Antioxidant (natural and synthetic) } \\
\hline$\alpha$-tocopherol & $37.35 \pm 1.15$ & & \\
\hline BHT & $3.63 \pm 0.96$ & & \\
\hline
\end{tabular}

RSC of $40.0 \mathrm{~L} / \mathrm{mol} \mathrm{gs}$ and others purified compounds showed an RSC below $5.0 \mathrm{~L} / \mathrm{mol} \mathrm{gs}$.

\section{Conclusions}

All exotic fruits assayed in this study showed high potential as natural antioxidant source. Camu-camu had the highest antioxidant activity and presented an antioxidant activity higher than $\alpha$ tocopherol.

\section{Acknowledgements}

To CAPES, CNPq, EMBRAPA, UFERSA and European Union (FP6 Contract no.: 0015279) for financial support.

\section{Appendix A. Supplementary data}

Supplementary data associated with this article can be found, in the online version, at doi: 10.1016/j.foodres.2010.07.002.

\section{References}

Aruoma, O. I. (1998). Free radicals, oxidative stress, and antioxidants in human health and disease. Journal of the American Oil Chemists' Society, 75, 199-212.

Brand-Williams, W., Cuvelier, M. E., \& Berset, C. (1995). Use of free radical method to evaluate antioxidant activity. LWT-Food Science and Technology, 28, 25-30.

Chimi, H., Cillard, J., Cillard, P., \& Rahmani, M. (1991). Peroxyl and hydroxyl radical scavenging activity of some natural phenolic antioxidants. Journal of the American Oil Chemists' Society, 68, 307-312.

Di Matteo, V., \& Esposito, E. (2003). Biochemical and therapeutic effects of antioxidants in the treatment of Alzheimer's disease, Parkinson's disease, and amyotrophic lateral sclerosis. Current Drug Targets-CNS and Neurological Disorder, 2, 95-107.

Espin, J. C., Soler-Rivas, C., Wichers, H. J., \& García-Viguera, C. (2000). Anthocyaninbased natural colorants: A new source of antiradical activity for foodstuff. Journal of Agriculture and Food Chemistry, 48, 1588-1592.

Gerber, M., Boutron-Ruault, M. C., Hercberg, S., Riboli, E., Scalbert, A., \& Siess, M. H. (2002). Food and cancer: State of the art about the protective effect of fruits and vegetables. Bulletin du Cancer, 89, 293-312.

Kris-Etherton, P. M., Hecker, K. D., Bonanome, A., Coval, S. M., Binkoski, A. E., \& Hilpert K. F. (2002). Bioactive compounds in foods: Their role in the prevention of cardiovascular disease and cancer. American Journal of Medicine, 113(9B), 71S-88S.

Marquardt, D. (1963). An algorithm for least-squares estimation of nonlinear parameters. Journal of the Society for Industrial and Applied Mathematics, 11 $431-441$.

Moskovitz, J., Yim, M. B., \& Chock, P. B. (2002). Free radicals and disease. Archives of Biochemistry and Biophysics, 397, 354-359.

Mukai, K., Morimoto, H., Kikuchi, S., \& Nagaoka, S. (1993). Kinetic study of free-radicalscavenging action of biological hydroquinones (reduced forms of ubiquinone, vitamin K and tocopherol quinone) in solution. Biochimica et Biophysica Acta, 1157 313-317. 
Noguchi, C., \& Nikki, E. (2000). Phenolic antioxidants: A rationale for design and evaluation of novel antioxidant drugs for atherosclerosis. Free Radical Biology $\mathcal{\sigma}^{\circ}$ Medicine, 28, 1538-1546.

Obanda, M., \& Owuor, P. O. (1997). Flavonol composition and caffeine content of green leaf as quality potential indicators of Kenyan black teas. Journal of the Science of Food and Agriculture, 74, 209-215.

Rattan, S. I. S. (2006). Theories of biological aging: Genes, proteins and free radicals. Free Radical Research, 40, 1230-1238.

Rice-Evans, C., \& Miller, N. J. (1995). Antioxidants-The case for fruits and vegetables in the diet. British Food Journal, 97, 35-40.

Rufino, M. S. M., Alves, R. E., Brito, E. S., Jiménez, J. P., Saura-Calixto, F., \& Mancini Filho, J. (2010). Bioactive compounds and antioxidant capacities of 18 non-traditional tropical fruits from Brazil. Food Chemistry, 121, 996-1002.

Rufino, M. S. M., Alves, R. E., Brito, E. S., Silveira, M. R. S., \& Moura, C. F. H. (2009). Quality for fresh consumption and processing of some non-traditional tropical fruits from Brazil. Fruits, 64, 361-370.
Sánchez-Moreno, C., Larrauri, J. A., \& Saura-Calixto, F. (1998). A procedure to measure the antiradical efficiency of polyphenols. Journal of the Science of Food and Agriculture, 76, 270-276.

Saura-Calixto, F., Goñi, I., Mañas, E., \& Abia, R. (1991). Klason lignin, condensed tannins and resistant protein as dietary fiber constituents: Determination in grape pomaces. Food Chemistry, 39, 299-309.

Shahidi, F., Janitha, P. K., \& Wanasundara, P. K. (1992). Phenolic antioxidants. Critical Reviews in Food Science and Nutrition, 32, 67-103.

Shi, H., \& Niki, E. (1998). Stoichiometric and kinetic studies on Ginkgo biloba extract and related antioxidants. Lipids, 33, 365-370.

Strohecker, R., \& Henning, H. M. (1967). Análisis de vitaminas: Métodos comprobados. Madri: Paz Montalvo.

Suja, K. P., Jayalekshmy, A., \& Arumughan, C. (2004). Free radical scavenging behavior of antioxidant compounds of sesame (Sesamum indicum L.) in DPPH• system. Journal of Agriculture and Food Chemistry, 52, 912-915. 